\title{
The known unknown land. The history of study of north China in the XIX ${ }^{\text {th }}$ century
}

\begin{abstract}
This article is devoted to the history of Russian hypsometric and geographic investigations of the northern part of China, Mongolia, Manchuria, the Amur and the Ussuri region in the 19th century. The article is based on the analysis of numerous sources from the Russian State Historical Archive, St. Petersburg Branch of the Archive of the Academy of Sciences, Russian National Library, the Library of the Shanghai Zikawei Observatory. The article's methodological framework is objectivity concept, systematically of scientific analysis of archival materials.

The considerable attention is paid to H. Fritsche's, Palladius's, N.M. Przhevalsky's and other expeditions. The detailed analysis of a new systematic mapping of the northern part of China, made by the Russian scientists is given. The role of the Beijing Magneto-meteorological observatory in Beijing, as the part of the Russian Academy of sciences, is specially noted. The author considers in details the political and socioeconomic conditions of expeditions.
\end{abstract}

Keywords

North China $\bullet$ Russian Academy of Science $\bullet$ Beijing

(C) University of Warsaw - Faculty of Geography and Regional Studies
Tatiana Yurievna Feklova

Saint-Petersburg Branch of the Institute for the History of Science and Technology, Saint-Petersburg, Russia

e-mail: tat-feklova@yandex.ru

Received: 10 November 2018

Accepted: 26 February 2019
Introduction

From the eighteenth until the beginning of the twentieth century, China, with its self-isolation policy, was a difficult country to explore. An unwillingness to import foreign goods or adopt foreign experience led to China being vulnerable to the interests (and intervention) of other countries. After the Second Opium War (1856-1860) China became England's half-colony (central and southern of China); while, at that time, the north of China came under the strong influence of the Russian Empire. Between 1891 and 1916 the Trans-Siberian Railway from SaintPetersburg to Vladivostok was built. During 1897-1903 the Chinese Eastern Railway, or CER, was put into practice as the southern branch of the Trans-Siberian railway (de facto). The railroad line was built under Imperial Russia with a concession from the Qing dynasty, and linked Chita and Vladivostok with the Russian Far East. CER belonged to the Russian Empire and was constructed by its subjects. The construction of the line was a step towards increasing the influence of the Russian Empire in Far East and strengthening the Russian military presence on the Yellow Sea and in Manchuria. Manchuria was gradually absorbed into the sphere of Russian commercial and political interests. The investigation of this territory in order to map Manchuria, especially in the area of the CER, was very important for the Military Ministry and the Russian government (See Appendix 1).

The exploration of China by Russian scientists was closely connected with the creation of the Russian Orthodox Mission (ROM) (Figure 1). The Orthodox Mission in Beijing existed from 1715 to 1955 and had multiple functions beyond its scientific work. With official diplomatic offices being absent (the Russian embassy in Beijing was only opened in 1861), the Russian
Empire could potentially direct policy in China only through the ROM. For the Russian Empire it was a great chance to carry out diplomacy, scientific, and trade work under the cover of the ROM. The Mission was a unique organization, created not only to function as a religious mission and as a diplomatic agency, but also as the center of the Russian scientific organization in Beijing. ROM maintained close cooperation with the Russian Academy of Sciences (RAS) during its scientific investigation of China.

Why was it so important to investigate the northern part of China, Manchuria, Mongolia, and Central Asia? Why did

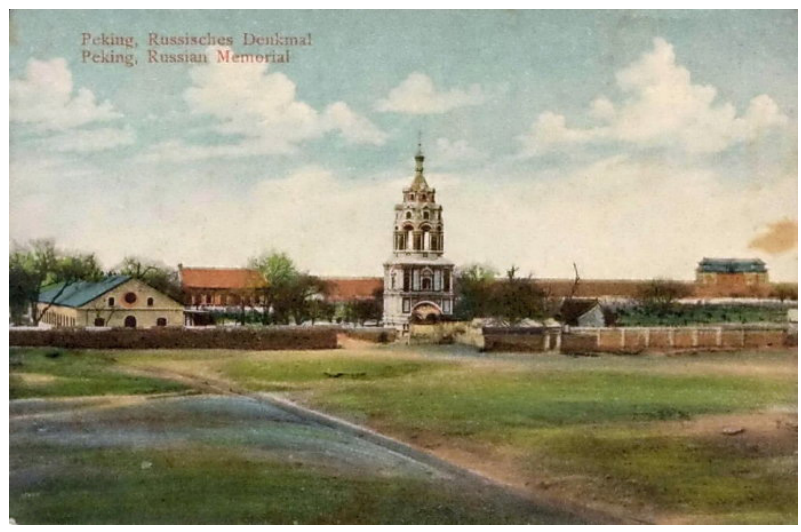

Figure 1. The view of Russian Orthodox mission in Beijing Source: https://vk.com/photo-28892034_266396769 
MISCELLANEA GEOGRAPHICA - REGIONAL STUDIES ON DEVELOPMENT

Vol. 23 • No. 3 • 2019 • pp. 125-130 • ISSN: 2084-6118 • DOI: 10.2478/mgrsd-2019-0013

Table 1. Fuss' measurements

\begin{tabular}{|c|c|c|c|}
\hline Place & $\begin{array}{l}\text { East Longitude } \\
\text { By researcher/modern }{ }^{1}\end{array}$ & $\begin{array}{l}\text { North Latitude } \\
\text { By researcher/modern }\end{array}$ & $\begin{array}{l}\text { Altitude above sea level } \\
\text { By researcher/modern (meters) }\end{array}$ \\
\hline Urga (modern Ulaanbaatar) & $\begin{array}{c}106^{\circ} 49^{\prime} 6^{\prime \prime} / 106^{\circ} 52^{\prime} 59^{\prime \prime} \\
\text { East Longitude }\end{array}$ & $\begin{array}{l}47^{\circ} 55^{\prime} 0^{\prime \prime} / 47^{\circ} 54^{\prime} 27^{\prime \prime} \\
\text { North Latitude }\end{array}$ & $1386 / 1284$ \\
\hline Sair-usu & $\begin{array}{l}106^{\circ} 56^{\prime} 4 " \text { "na. } \\
\text { East Longitude }\end{array}$ & $\begin{array}{l}44^{\circ} 47^{\prime} 2{ }^{\prime \prime} / \text { na. } \\
\text { North Latitude }\end{array}$ & 1097 /na. \\
\hline $\begin{array}{c}\text { Xar Moron river (in Inner } \\
\text { Mongolia) }\end{array}$ & $\begin{array}{c}111^{\circ} 13^{\prime} 6^{\prime \prime} / \text { Headwater } \\
116^{\circ} 56^{\prime} 52^{\prime \prime} \\
\text { River mouth } 120^{\circ} 46^{\prime} 39^{\prime \prime} \\
\text { East Longitude }\end{array}$ & $\begin{array}{c}42^{\circ} 24^{\prime} 7^{\prime \prime} / \text { na Headwater } \\
42^{\circ} 53^{\prime} 16^{\prime \prime} \\
\text { River mouth } 43^{\circ} 25^{\prime} 58^{\prime \prime} \\
\text { North Latitude }\end{array}$ & 1116/na. \\
\hline Kalgan (modern Zhangjiakou) & $\begin{array}{c}114^{\circ} 53^{\prime} 1^{\prime \prime} / 114^{\circ} 52^{\prime} 74^{\prime \prime} \\
\text { East Longitude } \\
\end{array}$ & $\begin{array}{c}40^{\circ} 50^{\prime} 7^{\prime \prime} / 40^{\circ} 48^{\prime} 6^{\prime \prime} \\
\text { North Latitude }\end{array}$ & $817 / 716$ \\
\hline Pekin (modern Beijing) & $\begin{array}{c}116^{\circ} 28^{\prime} 6^{\prime \prime} / 116^{\circ} 23^{\prime} 50^{\prime \prime} \\
\text { East Longitude }\end{array}$ & $\begin{array}{c}39^{\circ} 56^{\prime} 8^{\prime \prime} / 39^{\circ} 54^{\prime} 26^{\prime \prime} \\
\text { North Latitude }\end{array}$ & na./ 49 \\
\hline
\end{tabular}

Source: Fritsche 1874

the Russian scientists combine their scientific aims with their practical commercial, trade, and diplomatic aims? What impact did the political, economic and cultural intervention have on these territories? This article aims to provide answers to these questions by looking into the characteristics and evolution of the Russian expeditions to northern China and other territories. A brief background of the Russian Orthodox mission, and the Russian Magneto-Meteorological Observatory (RMMO), is provided together with an explanation of some of the significant aspects that have had an impact on the history of the investigations.

\section{Methodological issues}

Three methodological principles were combined in the article.

1. The systematic principle is the main methodological principle of this investigation. This implies considering the object of the study as a system; identifying its elements; establishing, classifying, and ordering the relations between these elements; and ensuring that the different elements are combined into a single entity.

2. Another principle is the comprehensive study of historical processes and phenomena. Any one historical phenomenon will be associated with other phenomena, but if it is studied in isolation it leads to distorted, erroneous conclusions.

3. The last one is the emergence principle. Emergence is the condition in which an entity has properties that its parts do not have, which is due to interactions between the parts. The investigation of China in the nineteenth century was not the sum of the RAS's researches, the RMMO's observations, or the investigations of the "independent" scientists - but the sum of all the institutes' investigations was the beginning of many new scientific disciplines, such as sinology, climatology and so on.

In methodological terms, this study is based on thorough documentary research.

Russian investigations into the northern part of China during the nineteenth century

The northern part of China and Manchuria, were under the direct control of the Manchu dynasty and all scientists needed special permission from the Chinese Emperor to carry out any investigations on this territory (Larichev 83)

The first attempts to map the huge territory of northern China were made by Jesuit monks in the middle of the eighteenth

\footnotetext{
${ }^{1}$ All modern data is from free access Internet sources.
}

century. During $1756-1759$, by the order of the Chinese Emperor Qianlong, Jesuits Felix de Rocha (Felix d'Rocha) and Jose de Espinha (Joseph d'Espinha) made a range of geographical investigations along the Russian-Chinese border. As a result, a map of this territory was created. According to the edict of Emperor Qianlong in 1740, Manchuria was closed to both Chinese and foreigners.

\section{Expeditions 1830-1832}

The hypsometric studies (measuring the heights of the landforms) of Central Asia, Northern China, Mongolia, Manchuria, and the Amur region in 1829, were continued by the Prussian scientist, Alexander von Humboldt, and again during 1830-1832 by the Russian scientists, Egor Fuss and Alexander Bunge during their trip from St. Petersburg to Beijing. However, this was a very short and sporadic investigation.

The Russian Magneto-Meteorological establishment

A new era in geographical investigations began in the second half of the nineteenth century for China's north, Mongolia, Manchuria, the Amur, and the Ussuri regions. In 1848 the Russian Academy of Sciences established the RMMO permanently on the territory of the ROM (China). It became a coordinating center for astronomical, meteorological, geographical, and hypsometric research for the Far East Asian region. The director of this observatory always helped Russian scientists with special tools and the processing of results.

After the Second Opium War between the Russian and the Chinese Empires, two agreements were concluded: in 1858, the Tianjin agreement; and in 1860, the Beijing agreement. The Beijing agreement finally defined the border and regulated trade and diplomatic relations between Russia and China. Under this agreement, the Far East and the Amur region finally came under the jurisdiction of the Russian Empire and in 1860 the city of Vladivostok was founded. The border question and the consolidation of these territories under Russia intensified the research process. During the 1860's and 1870's the Russian Military Ministry, the Naval Ministry, the Financial Ministry, the Ministry of National Education, among others, sent out many expeditions to these territories. Expeditions and investigations tended to involve those lands that were related to the economic life of the country.

The expedition of Archimandrite Palladius

From 1865 to 1878 Archimandrite Palladius headed the Russian Orthodox mission in China. He combined his leadership 


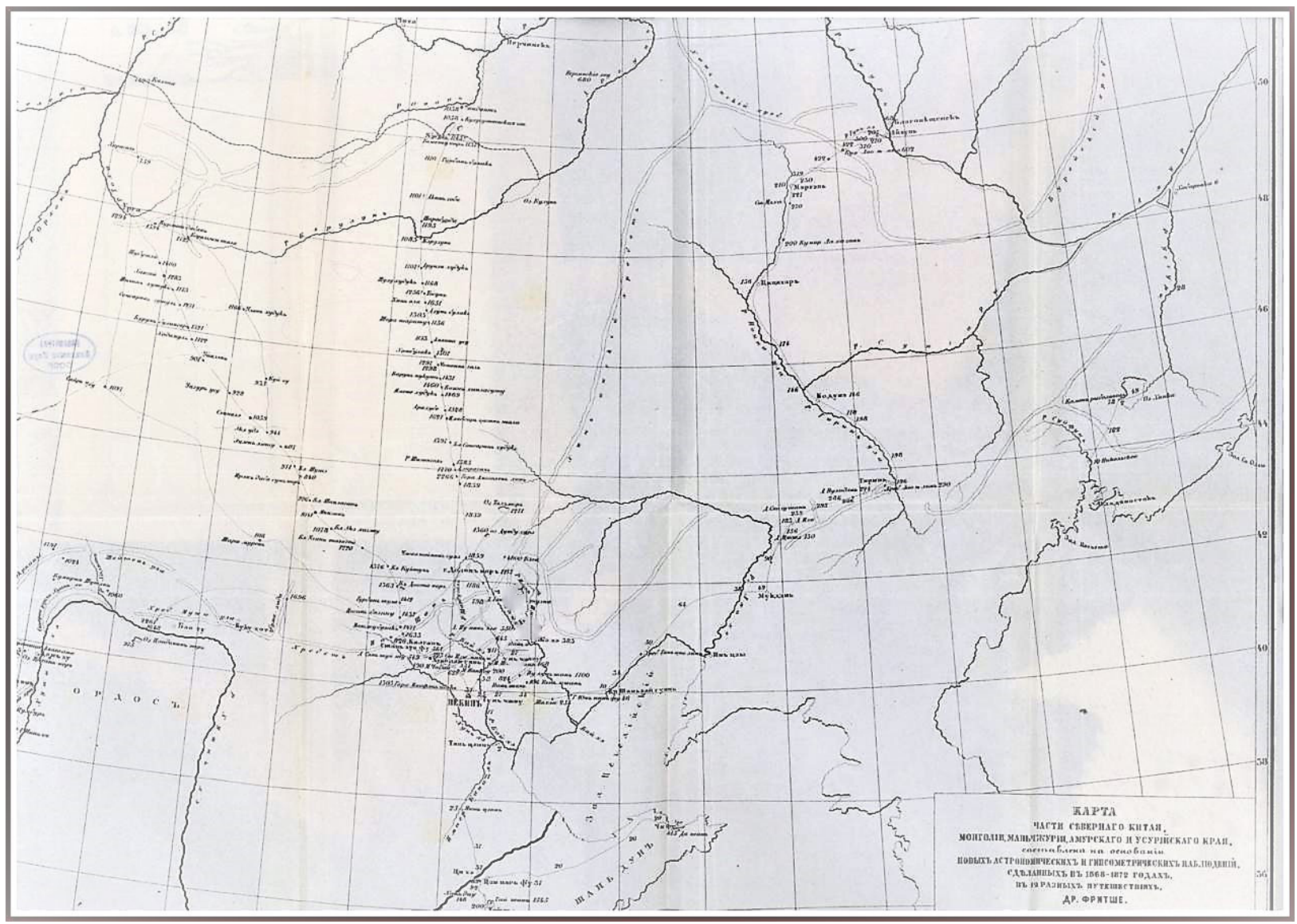

Figure 2. The map of part of North China, Mongolia, Manchuria, Amur and Usury region in $1868-1872$ Source: Fritsche, GA 1874, Page 40.

position within the Mission with successful scientific activities and became one of the early Russian sinologists. During his work as the leader of the fifteenth mission, Palladius cooperated with the Imperial Russian Geographical Society (IRGS).

In 1870, at the insistence of the IRGS, Palladius made an expedition to Manchuria, Amur, and Primorsky Krai. He was accompanied by the surveyor, Gabriel Navalny. Some astronomical and hypsometric tools (6 aneroid-barometers, 6 hypsometers, 1 universal astronomical tool, and 1 compass) were borrowed from the RMMO and were checked by its director, H. Fritsche. The expedition explored the territories of Manchuria and Amur. The main purposes of this expedition were ethnographical and historical investigations, but Palladius also did some hypsometric research. Palladius visited the provinces of Girin (modern Jilins), Qiqihar, Mukden (modern Shenyang), and Aigun, and also reached Blagoveshchensk (Russia) (ed. Khokhlov 1979). They then proceeded to Khabarovsk, visited Ussuri, and Lake Khanka, and then went on to Vladivostok. In the spring of 1871 Palladius and Navalny boarded a schooner named "East," and sailing the Pacific Ocean, inspected the Novgorod post, Nakhodka Bay, and Olga Bay, returning through Nagasaki to Beijing.

During the trip, the remains of ancient cities, fortifications, sea ports, and former trade routes of the Far East were discovered, and rich data were collected from the Manchurian area. For example, Palladius determined the height above sea level of the cities of Mukden- 49 meters (modern - 55 meters), Qiqihar 156 meters (modern - 147 meters), and Blagoveshchensk - 68 meters (modern - 131) (Fritsche, 1874).
A decision by the Russian Geographical Society led to Palladius being awarded a gold medal for his participation in this expedition.

\section{The expedition by N.M. Przhevalsky}

In the same year (1870), N.M. Przhevalsky made his first expedition to Central (Inner) Asia. In early November 1870 he received permission from the Chinese authorities to visit Beijing and Manchuria. The last director of the RMMO, H. Fritsche, had checked all the instruments for Przhevalsky's expedition. Przhevalsky also used an aneroid-barometer and a hypsometer. To measure the distance of the Sun and the Pole star above the horizontal, he used a universal Pistor \& Martins' instrument with a clock. For magnetic declination he used the old system's compass, so there was a permanent variation of +4 '. During the eighteenth and nineteenth centuries a new discipline - the Earth's magnetism - was attracting more and more research. During the same centuries, the so called "Magnetic Crusade" to investigate Earth's magnetism across all territories began; with Przhevalsky making the first magnetic investigations in northern China using special tools from the RMMO (See Appendix 2).

At the end of his expedition in 1875, Przhevalsky expressed his gratitude to the director of the Observatory. "Finally, I must express my sincere gratitude to the Director of the Beijing Observatory Fritsche, who provided me with his advice on astronomical and magnetic observations and be sure to calculate all these observations" (Przhevalsky 1875-1876). 
The expedition of G.A. Mosin

In 1870, the Russian Consul for Urga, Ya.P. Shishmarev, organized an expedition for his assistant, G.A. Mosin (Dacyshen 2007), from Urga to Beijing. The main aim of the expedition was to organize a meteorological station in Urga. On his way, Mosin made astronomical observations and hypsometric investigations. For these, Mosin used an aneroid-barometer and a mercury barometer, which he had borrowed from the RMMO. The following year he repeated his expedition, but he used a more modern normal barometer from J. Geißler (See Appendix 2).

The expedition of $\mathrm{H}$. Fritsche

The series of expeditions were continued with an expedition made by the director of the RMMO, $\mathrm{H}$. Fritsche, who made scientific investigations in Mongolia. Here he conducted meteorological observations and recorded the latitude and longitude of all the places he visited (Figure 2). He also made astronomical and climate studies in the Hinggan area of China (Inner Mongolia Autonomous Region of the People's Republic of China). For barometric investigations, Fritsche used the Geißler' thermometer from the RMMO. His work contributed to the clarification of the orographic characteristics of northern China and Mongolia's maps, and corrected the representation of the reliefs of these territories. The Russian astronomer, Ferdinand Lütke, mentioned that $\mathrm{H}$. Fritsche "tries to expand our geographical knowledge of Central Asia."

In 1872 Fritsche sent a book to the Russian Academy of Sciences that contained his astronomical observations concerning the exact location of the RMMO. The determination of the astronomical position of the Beijing observatory was an important task in the mapping of the territory of China and Mongolia. The observatory was the starting point for all geographical, meteorological, and magnetic investigations of north-east China (Notes of the Imperial Academy of Sciences 1872).

\section{Conclusion}

The northern part of China was a doubly closed country because China followed a policy or self-isolation, and Manchuria was prohibited to non-Manchurian citizens. The expeditions also tried to consider two aims: scientific and, trade and diplomatic, both for Russian science (a huge unexplored territory) and for the government of the Russian Empire (for example, for future railway lines). In the second half of the nineteenth century the huge territory of the Far East was included in the Russian Empire. In order to include these territories in the economic and political sphere of the Russian Empire, Russian scientists had to investigate and map them.

The results of all these expeditions were the determination of the heights of many places in the north of China and the Russia's Far East, for example, Galangal (Jenzano - urban region in the province of Hebei, China) and Urga (modern Ulaanbaatar - capital of Mongolia) (Fritsche 1872). During the expedition, numerous meteorological, astronomical, and hypsometric observations were made. These studies were important both in scientific and strategic terms. Russian scientists were the first to make complex investigations in the Chinese north, Manchuria, Mongolia, and Central (Inner) Asia.

Appendix 1. Expeditions mentioned in the article

\begin{tabular}{|c|c|c|}
\hline Date & Person & Place \\
\hline $1756-1757$ & Felix de Rocha, Jose d'Espinha & Russian-Chinese border \\
\hline $1830-1832$ & Egor Fuss & Northern China, Mongolia, Manchuria, Amur region \\
\hline 1870 & Archimandrite Palladius & Manchuria, Amur region \\
\hline 1870 & N.M. Przhevalsky & $\begin{array}{c}\text { Central (Inner) Asia, Northern China, Mongolia, } \\
\text { Manchuria }\end{array}$ \\
\hline 1870 & G.A. Mosin & Northern China, Mongolia, Manchuria \\
\hline 1873 & H. Fritsche & Northern China, Mongolia, Manchuria \\
\hline
\end{tabular}

Source: own elaboration.

Appendix 2. Elevation table for the expeditions of N.M. Przhevalsky and G.A. Mosin in 1871, between Kyakhta (Republic of Buryatia, Russia) and Beijing (China)

\begin{tabular}{|c|c|c|c|}
\hline Name of place & $\begin{array}{c}\text { Distance from Beijing (in } \\
\text { Russian verst) }\end{array}$ & Height above sea level & Observer \\
\hline Beijing & 0 & 37.5 & H. Fritsche \\
\hline Nan-kou & 50 & 200 & N.M. Przhevalsky \\
\hline Beyond the Guan-Gow gorge & 62 & 580 & G. Mosin \\
\hline Chadao & 62.5 & 629 & G. Mosin \\
\hline Huai-lai-xiang city & 64.5 & 572 & N.M. Przevalsky \\
\hline
\end{tabular}


Appendix 2. Elevation table for the expeditions of N.M. Przhevalsky and G.A. Mosin in 1871, between Kyakhta (Republic of Buryatia, Russia) and Beijing (China)

\begin{tabular}{|c|c|c|c|}
\hline Name of place & $\begin{array}{c}\text { Distance from Beijing (in } \\
\text { Russian verst) }\end{array}$ & Height above sea level & Observer \\
\hline Ji-min-yi station & 134 & 523 & G. Mosin \\
\hline Xiang-shui-pu village & 150 & 549 & G. Mosin \\
\hline Xuan-hua-fu city & 165 & 567 & G. Mosin \\
\hline Kalgan (Zhangjiakou) & $\begin{array}{l}200 \\
200\end{array}$ & $\begin{array}{l}788 \\
871\end{array}$ & $\begin{array}{l}\text { G. Mosin } \\
\text { N.M. Przhevalsky }\end{array}$ \\
\hline Highest point of the pass & $\begin{array}{l}225 \\
225\end{array}$ & $\begin{array}{l}1,636 \\
1,630\end{array}$ & $\begin{array}{l}\text { N.M. Przhevalsky } \\
\text { N.M. Przhevalsky }\end{array}$ \\
\hline Manzhu-bulak & 238 & 1,411 & N.M. Przhevalsky \\
\hline Tsagan - Balgas & 265 & 1,437 & G. Mosin \\
\hline Gurban-Tulgu & $\begin{array}{l}300 \\
300\end{array}$ & $\begin{array}{l}1,417 \\
1,407\end{array}$ & $\begin{array}{l}\text { G. Mosin } \\
\text { G. Mosin }\end{array}$ \\
\hline Khar-Us Lake & 330 & 1,366 & G. Mosin \\
\hline Hermo & 325 & 1,408 & G. Mosin \\
\hline Daota-nor & 365 & 1,322 & G. Mosin \\
\hline $\begin{array}{l}\text { Kuytun (Ili Kazakh Autonomous } \\
\text { Prefecture, Xinjiang, China) }\end{array}$ & $\begin{array}{l}402 \\
360\end{array}$ & $\begin{array}{l}1,390 \\
1,419\end{array}$ & $\begin{array}{l}\text { G. Mosin } \\
\text { G. Mosin }\end{array}$ \\
\hline Ongotsa & 388 & 1,280 & N.M. Przhevalsky \\
\hline Shabartai & 390 & 1,414 & G. Mosin \\
\hline Ulan-hada & 420 & 1,399 & G. Mosin \\
\hline Chuluntay ongots & 442 & 1,257 & G. Mosin \\
\hline Huduk & 460 & 1,322 & G. Mosin \\
\hline Ulan-tologoi & $\begin{array}{l}485 \\
443\end{array}$ & $\begin{array}{l}1,252 \\
1,077\end{array}$ & $\begin{array}{l}\text { G. Mosin } \\
\text { N.M. Przhevalsky }\end{array}$ \\
\hline Shire & 462 & 1,173 & G. Mosin \\
\hline Ehin-shinda & 477 & 1,060 & G. Mosin \\
\hline Halganey Usu & 517 & 1,006 & G. Mosin \\
\hline Eke-hachzhu & 552 & 937 & G. Mosin \\
\hline Borolchi & 555 & 1,290 & G. Mosin \\
\hline Mingan & 597 & 1,041 & G. Mosin \\
\hline Hara-boro-hoan tola & 605 & 877 & G. Mosin \\
\hline Shatszagan & $\begin{array}{l}635 \\
608\end{array}$ & $\begin{array}{l}931 \\
945\end{array}$ & $\begin{array}{l}\text { G. Mosin } \\
\text { N.M. Przhevalsky }\end{array}$ \\
\hline Hultain-gobi & 657 & 950 & G. Mosin \\
\hline Irena-dobasun-nor & 687 & 840 & G. Mosin \\
\hline Arshantu & 710 & 973 & G. Mosin \\
\hline Shute & 727 & 971 & G. Mosin \\
\hline Etszen-Hoshu & 762 & 607 & G. Mosin \\
\hline
\end{tabular}


MISCELLANEA GEOGRAPHICA - REGIONAL STUDIES ON DEVELOPMENT

Vol. $23 \cdot$ No. $3 \cdot 2019 \cdot$ pp. 125-130 •ISSN: 2084-6118 • DOI: 10.2478/mgrsd-2019-0013

Appendix 2. Elevation table for the expeditions of N.M. Przhevalsky and G.A. Mosin in 1871, between Kyakhta (Republic of Buryatia, Russia) and Beijing (China)

\begin{tabular}{|c|c|c|c|}
\hline Name of place & $\begin{array}{c}\text { Distance from Beijing (in } \\
\text { Russian verst) }\end{array}$ & Height above sea level & Observer \\
\hline Eke-Ude & 822 & 955 & 933 \\
G. Mosin
\end{tabular}

\section{References}

Dacyshen, VG 2007, 'Енисейский казак Г. А. Мосин в истории Отечества', Енисейская провинция: альманах ('The Yenisei Cossack in the history of the Homeland', Yenisei province: almanac). Красноярск, vol. 3, pp. 64-70.

Dacyshen, VG 1993, 'Русские в Северной Маньчжурии' ('Russians in Northern Manchuria'), Россия и ATP, no 2, pp. 144-150.

Fritsche, GA 1873, 'Сведения о путешествии Фритше по Монголии' (Information about the expedition Fritche in Mongolia'), Известия ВСОИРГО, vol. IV, no. 5, pp. 235-239.

Fritsche, GA 1874, Гипсометрические и географические определения точек, основанные на наблюдениях, сделанных в 1868-1872 годах в 12-ти разных путешествиях по северному Китаю ('Geometric and geographical definitions of points based on observations made between 1868-1872 on 12 different journeys through Northern China'). Санкт-Петербург.

Извлечение из протоколов заседаний Академии наук (Extract from the report of meetings of the Academy of Sciences).1872, Записки Императорской Академии наук, vol. 20, Saint-Petersburg.

Khokhlov, AN (ed.) 1979, 'Новые материалы о путешествии П. И. Кафрарова по Дальнему Востоку в 1870-1871 гг.' ('New materials about P. I. Kafarov's expedition through the Far East in 1870-1871'), П. И. Кафраров и его вклад в отечественное востоковедение (к 100-летию со дня смерти), МоскваЖ Наука, vol. 3, pp. 101-111.

Larichev, VE 2012, 'Кафраровский проект: источники и документы первой историко-археологической и этнографической экспедиции Русского императорского географического общества в Маньчжурию, Приамурский и Южно-Уссурийский края (подготовка публикации «потерянных» дневников архим. Палладия Кафарова, руководителя экспедиции 1870-1871 годов)' ('Kafar project: sources and documents of the first historical, archaeological and ethnographic expedition of the Russian Imperial geographical society in Manchuria, Amur and South Ussuri region (preparation of the publication of "lost" diaries Archim. Palladium Kafarova, head of the expedition 1870-1871)', Вестник НГУ, vol. 11, no. 10, pp. 77-85.

Nevanlinna, H \& Häkkinen, L 2010, 'Results of Russian geomagnetic observatories in the 19-th century: magnetic activity, 1841-1862', Annales Geophysicae, vol. 28. No. 4, pp. 917-926.

Przhevalsky, NM 1875-1876, Монголия и страна тангутов. Трехлетнее путешествие в Восточной нагорной Азии ('Mongolia and Tangut country. A three-year expedition in Eastern mountainous Asia'). T. 1-2. Русское географическое общество, Санкт- Петербург.

Санкт-Петербургский филиал Архива Академии наук (СПбФ APAH). Ф. 337. Оп. 1. Д. 30. (St. Petersburg branch of the Academy of Sciences Archive (SPbF ARAN). F. 337. L. 1. F. 30)

СПбФ АРАН. Ф. 337. Оп. 1. Д. 391. (SPbF ARAN. F. 337. L. 1. F. 391) 